\title{
KEEFEKTIFAN COOPERATIVE LEARNING STAD DAN NHT DITINJAU DARI KEMAMPUAN KOMUNIKASI DAN PEMECAHAN MASALAH MATEMATIKA
}

\author{
Ayi Ahmad Maulana Yusup \\ Universitas Indraprasta PGRI, Jakarta, Indonesia \\ ayiahmad.my@gmail.com
}

\begin{tabular}{ll}
\hline & \\
Received: & 25 November 2020 \\
Revised: & 29 Januari 2021 \\
Accepted: & 18 Februari 2021
\end{tabular}

Accepted: 18 Februari 202

\section{Abstract} menghitung, tetapi juga berkaitan dengan kemampuan menyelesaikan permasalahan dan kemampuan komunikasi. Didapatkan informasi awal bahwa saat pembelajaran matematika guru hanya menggunakan metode pembelajaran yang sifatnya satu arah, guru mendominasi dalam pembelajaran, siswa hanya mendengarkan, mengerjakan tugas, kemudian dinilai, siswa juga malas untuk bertanya terkait dengan materi, siswa belum memahami rumus mana yang tepat untuk setiap pertanyaan yang diajukan pendidik, sehingga menyebabkan keterampilan berbicara dan menyelesaikan dari setiap persoalan siswa masih rendah. Oleh karena itu, untuk meningkatkan kemampuan komunikasi dan pemecahan masalah, peneliti memanfaatkan metode pembelajaran kooperatif tipe STAD dan NHT. Tujuan dari penelitian ini adalah untuk mengetahui pengaruh penggunaan model Pembelajaran terhadap kemampuan komunikasi dan pemecahan masalah matematika baik secara multivariat maupun parsial. Desain Penelitian ini adalah eksperimen, dengan sampel berjumlah 70 peserta didik kelas VII SMP Swasta di kota Tangerang selatan, terdiri dari SMP PGRI 1 Ciputat dipilih sebanyak 35 siswa sebagai kelas eksperimen (A1) Student Teams-Achievement Divisions (STAD) dan dari SMP Darussalam dipilih sebanyak 35 siswa sebagai kelas eksperimen (A2) Numbered head together (NHT). Hasil penelitian menunjukan bahwa (1). Terdapat pengaruh yang signifikan model pembelajaran terhadap kemampuan komunikasi dan pemecahan masalah matematika secara Multivariat. Implikasi dari penelitian ini yaitu bahwa pemanfaatan metode pembelajaran yang dipilih seorang guru di sekolah sangatlah penting, untuk meningkatkan motivasi belajar siswa, dan untuk menciptakan pembelajaran Matematika menjadi lebih menarik, supaya peserta didik mempunyai kemampuan komunikasi matematika yang baik, dan juga dapat meningkatkan kemampuan pemecahan masalah matematika siswa.

Keywords: Metode STAD; NHT; Kemampuan Komunikasi; Pemecahan Masalah Matematika

(*) Corresponding Author: $\quad$ Yusup, ayiahmad.my@gmail.com

How to Cite: Yusup, A. A. M. (2021). Keefektifan Cooperative Learning STAD Dan NHT Ditinjau Dari Kemampuan Komunikasi Dan Pemecahan Masalah Matematika. Research and Development Journal of Education, 7 (1), 80-89.

\section{INTRODUCTION}

Matematika adalah bagian dari sains yang melatarbelakangi pertumbuhan ilmu pengetahuan dan teknologi. Oleh karena itu, matematika dianggap seperti ilmu yang sistematis, saling terikat, memiliki cara pandang secara global (Muhammad et al., 2017). Melalui belajar matematika, siswa mendapatkan kesempatan untuk mengembangkan asumsi secara terpadu dan tersusun, rasional, dan responsive dalam mengkomunikasikan 
gagasan dan mampu memberikan solusi tekait persoalan matematika yang dihadapinya (Muhammad et al., 2017). Senada dengan misi pembelajaran matematika yang terdapat pada National Council of Teacher of Mathematics (Muhammad et al., 2017) adalah (1) berlatih dalam percakapan, (2) berpikir secara logika, (3) belajar untuk menyelesaikan setiap masalah, (4) belajar untuk mengaitkan ide, (5) membangun perilaku konkret atau percaya terhadap matematika. Sejalan dengan yang diutarakan oleh Baroody (Muhammad et al., 2017) menyebutkan bahwasanya ada 2 hal yang melatarbelakangi mengapa kemampuan komunikasi matematika perlu ditingkatkan. Pertama, matematika sebagai bahasa, bukan hanya sebagai media untuk bernalar, instrument untuk menciptakan bentuk, memberikan solusi atas persoalan, melainkan matematika sebagai alat yang bermanfaat dalam membangun percakapan berbagai gagasan secara lugas, akurat, dan teliti. Kedua, pembelajaran matematika sebagai kegiatan sosial, matematika diharapkan dapat membangun hubungan dan percakapan.

Selain kemampuan berkomunikasi, problem atau soal matematika adalah suatu masalah yang harus dipecahkan, tetapi tidak semua soal adalah masalah (Juliani Noor \& Megawati, 2014). Secara global, dapat disimpulkan bahwa pemecahan masalah adalah proses pengaplikasian ilmu yang didapatkan peserta didik sebagai pengalaman yang diperoleh dalam kondisi yang baru. Pemecahan masalah adalah kegiatan yang sangat pokok karena bertujuan untuk memberikan solusi dari setiap persoalan yang dihadapi dalam aktifitas sehari-hari (Juliani Noor \& Megawati, 2014). George Polya (Juliani Noor \& Megawati, 2014) mengatakan terdapat 4 langkah dalam pendekatan pemecahan masalah, sebagai berikut: (1) Menafsirkan masalah. Sejumlah soal yang harus ditampilkan kepada peserta didik dalam memahami masalah ini, antara lain: a) Apakah yang diketahui dari soal? b) Apakah yang ditanyakan soal? c) Apakah saja informasi yang diperlukan? (2) Program penyelesaian. Pertanyaan-pertanyaan yang muncul kepada siswa untuk membantunya dalam merencanakan penyelesaian adalah: a) Pernahkah anda menemukan soal seperti ini sebelumnya? b) formula yang dapat digunakan dalam masalah ini? c) Simak apa yang ditanyakan? d) Apakah strategi tersebut berkaitan dengan permasalahan yang akan dipecahkan? (3) Melaksanakan rencana. Jika siswa telah memahami permasalahan dengan baik dan sudah menentukan strategi pemecahannya, tahapan berikutnya yaitu merealisasikan pemecahan masalah sesuai dengan program yang telah dibuat. Keterampilan peserta didik Kemampuan memahami isi materi dan keterampilan siswa melakukan perhitungan matematika akan sangat membantu siswa untuk melaksanakan tahap ini. (4) Memeriksa Kembali. a) menyamakan hasil yang didapatkan dengan pertanyaan. b) Dapat dibuktikan kebenaran jawabannya.

Namun, kenyataan yang terjadi kemampuan komunikasi dan pemecahan masalah matematika belum dimiliki oleh semua peserta didik yang menjadi objek dalam penelitian ini. Berdasarkan data dari sebaran angket awal yang peneliti lakukan untuk peserta didik kelas VII di dua SMP Swasta Ciputat diperoleh hasil bahwa 66\% siswa atau 46 siswa dari 70 siswa belum dapat menginterprestasikan ide yang terdapat pada permasalahan/soal yang terdapat pada materi matematika yang sedang dipelajari, sehingga mereka kesulitan menemukan solusi atau cara yang tepat untuk menyelesaikan permasalahan tersebut. Siswa masih takut atau malu untuk bertanya, peserta didik ragu-ragu dalam menjawab pertanyaan dari guru, masih ada siswa yang mencontek saat mengerjakan tugas, siswa masih bingung menggunakan rumus yang tepat dari setiap soal yang berikan, Sebagian peserta didik merasakan bahwa matematika itu sulit, sehingga males untuk belajar matematika, matematika terlalu monoton dengan metode pembelajaran ceramah. Sedangkan 34\% siswa atau 24 siswa dari 70 siswa telah mampu berkomunikasi dan mampu menyelesaikan setiap permasalahan matematika.

Betapa pentingnya kemampuan komunikasi matematika yang harus dipunyai oleh siswa, salah satu cara dalam mengembangkan keterampilan komunikasi adalah dengan 
pembelajaran kooperatif. Pengajaran yang mengikut sertakan peserta didik bekerja dalam tim untuk menetapkan tujuan bersama. Pembelajaran kooperatif lebih mengutamakan kerjasa sama dalam tim, agar tercipta interaksi. Oleh sebab itu, peserta didik dapat berkomunikasi aktif dengan sesama temannya. Dengan komunikasi diharapkan siswa mampu menyelesaikan setiap permasalahan matematika dengan mudah. Berdasarakan permasalahan tersebut Guru dituntut lebih kreatif dalam memilih metode pembelajaran yang tepat untuk mencapai tujuan pembelajaran.

Model pembelajaran yang mengedepankan kerjasama dan interaksi antar peserta didik lebih diutamakan dalam dunia Pendidikan. Senada dengan hasil penelitian Slavin (Noor \& Husna, 2017) yang menyatakan bahwa: (1) pembelajaran kooperatif dapat meningkatkan prestasi belajar siswa, meningkatkan hubungan sosial, menumbuhkan sikap tolerasi dan menghargai pendapat orang lain, (2) pembelajaran kooperatif dapat memenuhi kebutuhan siswa dalam berpikir kritis, memecahkan masalah, dan mengintegrasi-kan pengetahuan dengan pengalaman. Banyak metode pembelajaran yang dapat digunakan dalam pembelajaran matematika, tugas guru untuk memlih metode yang tepat dan efektif agar tujuan pembelajaran tercapai (Sapitri \& Hartono, 2015). Peneliti memilih metode kooperatif STAD dan NHT.

Menurut Isjoni (Rahman, 2015) metode pembelajaran Student Teams Achievement Division adalah model pembelajaran yang berfokus pada peserta didik, dalam hal ini siswa belajar dan bekerjasama dalam tim, menghargai pendapat orang, memberikan kesempatan orang lain dalam mengemukakan ide dalam kelompok. Sehingga peserta didik dapat menjalin interaksi dan komunikasi guna mendapatkan nilai yang terbaik bagi kelompok, sekaligus membantu teman dalam memahami materi, sehingga diharapkan dapat membangkitkan gairah belajar peserta didik. Ada 4 hal yang harus diperhatikan dalam pembelajaran $S T A D$, yaitu mengajar, tim belajar, ujian, dan pengakuan tim (Rakhmawati, 2015). Metode STAD, siswa dibagi dalam kelompok terdiri atas empat orang yang memiliki perberbedaan dalam hal keterampilan, jenis kelamin dan etniknya. Guru memaparkan materi, kemudian peserta didik diarahkan untuk bekerja dalam tim mereka dan meyakinkan setiap siswa dalam kelompok telah menguasai materi yang ditugaskan. Kemudian peserta didik menyelesaikan tugas tentang materi yang telah disampaikan secara individu dan dilarang saling bekerjasama (Wahyuni \& Abadi, 2014). Diharapkan dengan adanya model pembelajaran kooperatif tipe STAD menunjang aspek kemampuan komunikasi siswa dan pemecahan masalah matematika.

Metode Numbered Head Together merupakan karakter pembelajaran kooperatif dari diskusi kelompok (Vhalery, 2019), di mana setiap peserta didik dalam tim mendapat angka (Yenni, 2016). Langkah-langkah penerapan NHT, Peserta didik dalam tim memiliki nomor yang berbeda kemudian secara tim saling bekerjasama untuk menjawab pertanyaan. Selanjutnya pendidik akan memanggil nomor yang mewakili peserta didik dalam tiap tim tersebut untuk memaparkan hasil diskusi timnya. Dengan adanya diskusi diharapkan peserta didik mampu memaparkan gagasan matematisnya dalam kelompok secara verbal. Kemudian hasil diskusi tersebut dituliskan pada lembar jawaban kelompok. Selanjutnya peserta didik yang nomornya dipanggil mengkomunikasikan ide matematisnya kepada guru dan siswa yang lain (Lagur et al., 2018). Dengan demikian, metode pembelajaran kooperatif tipe Numbered Head Together menunjang aspek komunikasi siswa serta pemecahan masalah matematika.

Penelitian ini dibatasi pada metode STAD dan NHT dalam komunikasi siswa dan pemecahan masalah dalam pembelajaran matematika pada siswa kelas VII di SMP PGRI 1 Ciputat dan SMP Darussalam tahun ajaran 2017-2018. Rumusan Masalah dalam penelitian ini adalah: (1) Apakah terdapat pengaruh model pembelajaran terhadap kemampuan komunikasi dan pemecahan masalah matematika secara multivariat? (2) Apakah terdapat pengaruh model pembelajaran terhadap kemampuan komunikasi 
matematika? dan (3) Apakah terdapat pengaruh model pembelajaran terhadap pemecahan masalah matematika?

\section{METHODS}

Metode dalam penelitian ini adalah metode eksperimen semu (kuasi eksperimmen) yaitu suatu metode yang terdapat 2 kelompok yaitu kelompok kelas eksperimen (model pembelajaran STAD) dan kelompok kelas eksperimen (model pembelajaran NHT) (Menanti \& Rahman, 2015). Metode penelitian dapat dilihat pada gambar 1.

Tabel 1.

Desain Penelitian

\begin{tabular}{|c|c|c|c|}
\hline \multicolumn{4}{|c|}{ Model Pembelajaran (A) } \\
\hline \multicolumn{2}{|c|}{ STAD (A1) } & \multicolumn{2}{|c|}{ NHT (A2) } \\
\hline Y1 & Y2 & Y1 & Y2 \\
\hline A1Y1 & A1Y2 & A2Y1 & $\mathrm{A} 2 \mathrm{Y} 2$ \\
\hline
\end{tabular}

Keterangan :

A : Model pembelajaran

A1 : Model pembelajaran kooperatif tipe STAD

A2 : Model pembelajaran kooperatif tipe NHT

Y1 : Kemampuan komunikasi Matematika

Y2 : Pemecahan masalah Matematika

A1Y1 : Kelompok siswa dengan model pembelajaran Student TeamsAchievement Divisions terhadap kemampuan komunikasi Matematika.

A1Y2 : Kelompok siswa dengan model pembelajaran Student TeamsAchievement Divisions terhadap pemecahan masalah Matematika.

A2Y1 : Kelompok siswa dengan model pembelajaran Numbered Head Together terhadap kemampuan komunikasi Matematika.

A2Y2 : Kelompok siswa dengan model pembelajaran Numbered Head Together terhadap pemecahan masalah Matematika.

Populasi penelitian yaitu peserta didik kelas VII di SMP PGRI 1 Ciputat dan SMP Darussalam dengan jumlah seluruhnya 709 siswa. Sampel penelitian terdiri dari SMP PGRI 1 Ciputat dipilih sebanyak 35 siswa sebagai kelas eksperimen (A1) Student TeamsAchievement Divisions (STAD) dan dari SMP Darussalam dipilih sebanyak 35 siswa sebagai kelas eksperimen (A2) Numbered head together (NHT). Teknik pengambilan sampel dilakukan secara purposive sampling. Sumber data diperoleh dari hasil post-test kemampuan komunikasi dan pemecahan masalah matematika. Teknik pengumpulan data melalui tes kemampuan komunikasi dan pemecahan masalah, angket, dan observasi. Tekhnik analisis data yang digunakan adalah analisis perbandingan dengan uji Multivariate Analysis of Varians (MANOVA)dengan menggunakan Software SPSS 24.

\section{RESULTS \& DISCUSSION}

Data penelitian yang telah didapatkan diolah untuk mengetahui simpulan dari penelitian. Pengolahan data diawali dengan mendeskripsikan data penelitian. Hasil penelitian uji deskriptif bisa dilihat pada tabel 1: 
Tabel 2.

Hasil Uji Deskriptif

\begin{tabular}{|c|c|c|c|c|c|}
\hline & $\mathbf{N}$ & Minimum & Maximum & Mean & Std. Deviation \\
\hline Kemampuan komunikasi & 35 & 62 & 90 & 7626 & 6861 \\
\hline Matematika kelas STAD & & & & 10,20 & 0,001 \\
\hline $\begin{array}{l}\text { Kemampuan komunikasi } \\
\text { Matematika kelas NHT }\end{array}$ & 35 & 55 & 82 & 71,00 & 6,557 \\
\hline Pemecahan Masalah & 35 & 70 & 92 & & \\
\hline Matematika kelas STAD & & & & 80,00 & 4,935 \\
\hline Pemecahan Masalah & 35 & 60 & 82 & 74,83 & 5,073 \\
\hline $\begin{array}{c}\text { Matematika kelas NHT } \\
\text { Valid N (listwise) }\end{array}$ & 35 & & & $1+, 0 J$ & נדוס, \\
\hline
\end{tabular}

Dari tabel 1 diketahui jumlah sampel pada kelas eksperimen sebanyak 35 orang di eksperimen 1 dan sebanyak 35 orang di kelas eksperimen 2. Nilai minimum (60), maksimum (90), mean (76,26), dan standar deviasi (6,861) untuk kemampuan komunikasi matematika kelas STAD. Nilai minimum (55), maksimum (82), mean (71), dan standar deviasi $(6,557)$ untuk kemampuan komunikasi matematika kelas NHT. Nilai minimum (70), maksimum (92), mean (80), dan standar deviasi $(4,935)$ untuk pemecahan masalah matematika kelas STAD. Nilai minimum (60), maksimum $(82)$, mean $(74,83)$, dan standar deviasi $(5,073)$ untuk pemecahan masalah matematika kelas NHT.

Pengujian berikutnya adalah uji normalitas data untuk mengetahui apakah data penelitian bersifat normal atau tidak normal.

Tabel 3.

Hasil Uji Normalitas

\begin{tabular}{|c|c|c|c|c|c|c|}
\hline & \multicolumn{3}{|c|}{ Kolmogorov-Smirnov ${ }^{a}$} & \multicolumn{3}{|c|}{ Shapiro-Wilk } \\
\hline & Statistic & Df & Sig. & Statistic & df & Sig. \\
\hline $\begin{array}{l}\text { Kemampuan_Komunikasi_ } \\
\text { Matematika_Kelas_STAD }\end{array}$ & .115 & 35 & $.200^{*}$ & .971 & 35 & .460 \\
\hline $\begin{array}{l}\text { Kemampuan_Pemecahan_M } \\
\text { asalah_Matematika_Kelas_S } \\
\text { TAD }\end{array}$ & .143 & 35 & .069 & .963 & 35 & .290 \\
\hline $\begin{array}{l}\text { Kemampuan_Komunikasi_- } \\
\text { Matematika_Kelas_NHT }\end{array}$ & .103 & 35 & $.200^{*}$ & .971 & 35 & .469 \\
\hline $\begin{array}{l}\text { Kemampuan_Pemecahan_M } \\
\text { asalah_Kelas_NHT }\end{array}$ & .134 & 35 & .114 & .940 & 35 & .055 \\
\hline
\end{tabular}

Berdasarkan tabel 2 pengujian dilakukan dengan menggunakan uji Kolmogorrov smirnov dengan keterangan adalah sama dengan uji liliefors. Didapat untuk kemampuan komunikasi matematika kelas STAD dan NHT $(0,200>0,05)$, karena tingkat signifikansi atau nilai probabilitas di atas 0,05 maka dikatakan distribusi kedua sampel adalah normal. Kemampuan pemecahan masalah matematika kelas STAD $(0,069>0,05)$ maka dinyatakan normal. Kemampuan pemecahan masalah matematika kelas NHT $(0,114>$ $0,05)$ maka dinyatakan normal.

Pengujian berikutnya adalah uji homogenitas data untuk mengetahui apakah data penelitian bersifat homogen atau tidak. 
Tabel 4.

Uji Homogenitas Matriks Kovarians

\begin{tabular}{cc}
\hline & ${\text { Box's Test of Equality of Covariance } \text { Matrices }^{\mathbf{a}}}$ \\
\hline Box's M &, 705 \\
F &, 228 \\
df1 & 3 \\
df2 & 832320,000 \\
Sig. &, 877 \\
\hline Sumber: Hasil Output SPSS versi 24.0
\end{tabular}

Dari tabel 3 memberikan hasil, yaitu nilai signifikansi adalah 0,877>0,05 dapat disimpulkan data homogen matriks kovarians.

Tabel 5.

Uji Homogenitas Varians

Sumber: Hasil Output SPSS versi 24.0

Dari tabel 4 homogenitas kemampuan Komunikasi Matematika menunjukkan bahwa nilai sig adalah 0,762 >0,05 dapat disimpulkan data homogen. Homogenitas pemecahan masalah Matematika menunjukan nilai sig 0,674>0,05 dan dapat disimpulkan data homogen.

Selanjutnya pengujian hipotesis penelitian dapat dilihat pada gambar 1 dan 2.

\begin{tabular}{|c|c|c|c|c|c|c|}
\hline \multicolumn{7}{|c|}{ Multivariate Tests $^{a}$} \\
\hline \multicolumn{2}{|l|}{ Effect } & Value & $\mathrm{F}$ & $\begin{array}{c}\text { Hypothesis } \\
\text { df }\end{array}$ & Error df & Sig. \\
\hline \multirow[t]{4}{*}{ Intercept } & $\begin{array}{l}\text { Pillai's } \\
\text { Trace }\end{array}$ & ,998 & $14192,456^{b}$ & 2,000 & 67,000 &, 000 \\
\hline & $\begin{array}{l}\text { Wilks' } \\
\text { Lambda }\end{array}$ & ,002 & $14192,456^{b}$ & 2,000 & 67,000 &, 000 \\
\hline & $\begin{array}{l}\text { Hotelling's } \\
\text { Trace }\end{array}$ & 423,655 & $14192,456^{b}$ & 2,000 & 67,000 & ,000 \\
\hline & $\begin{array}{l}\text { Roy's } \\
\text { Largest } \\
\text { Root }\end{array}$ & 423,655 & $14192,456^{b}$ & 2,000 & 67,000 & ,000 \\
\hline \multirow[t]{4}{*}{$\bar{A}$} & $\begin{array}{l}\text { Pillai's } \\
\text { Trace }\end{array}$ & ,332 & $16,625^{\mathrm{b}}$ & 2,000 & 67,000 &, 000 \\
\hline & $\begin{array}{l}\text { Wilks' } \\
\text { Lambda }\end{array}$ & ,668 & $16,625^{\mathrm{b}}$ & 2,000 & 67,000 &, 000 \\
\hline & $\begin{array}{l}\text { Hotelling's } \\
\text { Trace }\end{array}$ & ,496 & $16,625^{b}$ & 2,000 & 67,000 &, 000 \\
\hline & $\begin{array}{l}\text { Roy's } \\
\text { Largest } \\
\text { Root }\end{array}$ & ,496 & $16,625^{b}$ & 2,000 & 67,000 &, 000 \\
\hline \multicolumn{7}{|c|}{ a. Design: Intercept + A } \\
\hline \multicolumn{7}{|c|}{ b. Exact statistic } \\
\hline
\end{tabular}

Sumber: Hasil Output SPSS versi 24.0

Gambar 1.

Rangkuman MANOVA satu arah untuk Pengujian Hipotesis Multivariat 


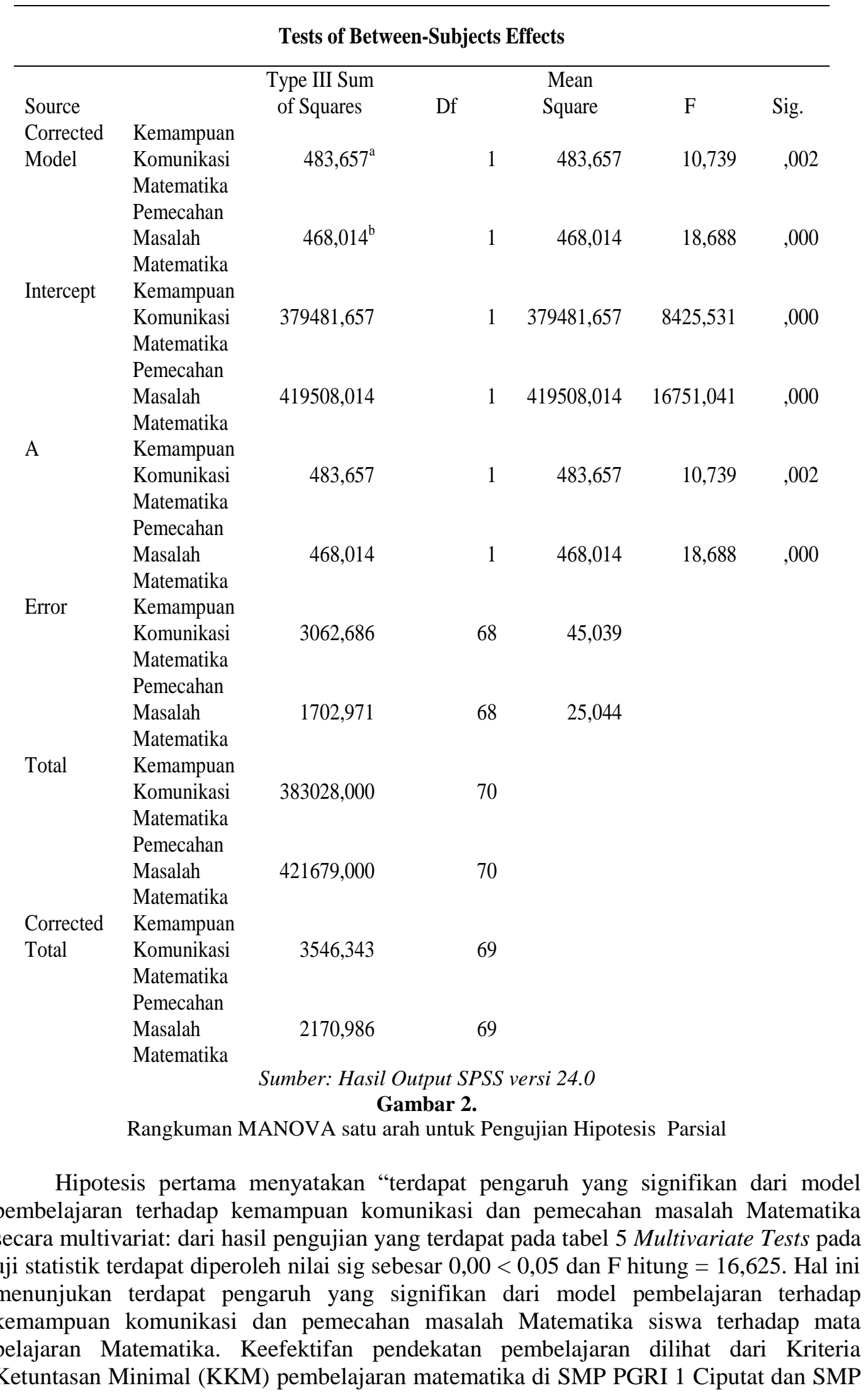


Darrussalam, pembelajaran dikatakan efektif jika rata-rata nilai kemampuan komunikasi matematika dan rata-rata nilai pemecahan masalah siswa lebih besar secara signifikan dari nilai KKM. Nilai KKM yang ditetapkan pihak sekolah pada mata pelajaran matematika yaitu 60,00 untuk skala $0-100$, dalam penelitian ini nilai ketuntasan untuk kemampuan komunikasi matematika siswa 60,00 pada skala 0-100. Begitu juga pada kemampuan pemecahan masalah matematika siswa, peneliti menetapkan nilai ketuntasan 60,00 pada skala 0-100. Sehingga dapat dikatakan bahwa kedua model pembelajaran tersebut efektif dalam meningkatakan kemampuan komunikasi dan pemecahan masalah matematika peserta didik. Selama proses pembelajaran dengan menggunakan kedua model pembelajaran tersebut berpusat pada siswa. Meskipun pada awal pembelajaran tetap guru yang menyampaikan materi, setelah itu setelah itu barulah siswa berdiskusi menyelesaikan lembar kerja yang diberikan oleh guru. Siswa berpartisipasi aktif melalui diskusi dalam kelompoknya. Proses selanjutnya setelah diskusi yaitu memaparkan hasil diskusi di depan kelas dan di tanggapi oleh kelompok lain. Selain itu, siswa diberikan penghargaan sehingga siswa menjadi senang dan terpacu untuk belajar, dan menjadi semangat dalam mengikuti pembelajaran. Proses tersebut memberikan pengaruh yang positif ditinjau dari kemampuan komunikasi matematika siswa dan pemecahan masalah matematika siswa sehingga pembelajaran berjalan efektif. Siswa lebih bersemangat dalam menyampaikan materi yang menjadi tugasnya, lebih bisa berkomunikasi dengan teman sebaya, lebih memahami dalam setiap pertanyaan yang diajukan teman sebaya maupun guru, lebih terarah dalam menjawab setiap pertanyaan, mudah berinteraksi. Dalam pembelajaran STAD dan NHT ada tahap kerja kelompok dalam menuntaskan soal yang telah disiapkan guru, serta pemberian soal kuis kepada setiap siswa yang dikerjakan secara individu dalam hal ini peserta didik diharapkan mampu bernalar secara rasional dalam menyelesaikannya. Penelitian ini senada dengan penelitian (Sapitri \& Hartono, 2015) yang menunjukkan bahwa pembelajaran kooperatif tipe STAD dan GI keduanya efektif. Tidak terdapat perbedaan keefektifan diantara keduanya ditinjau dari kemampuan berpikir kritis dan kemampuan komunikasi matematis siswa pada pembelajaran himpunan di kelas VII.

Hipotesis kedua menyatakan "Terdapat pengaruh signifikan dari model pembelajaran terhadap kemampuan komunikasi matematika pada pembejaran Matematika" : dari hasil pengujian yang terdapat pada tabel 6 Tests of Between-Subjects Effectsdi atas yang merupakan tabel utama yang mempresentasikan hasil hipotesis yang diajukan peneliti. Diperoleh nilai sig sebesar 0,002 $<0,05$ dan F hitung $=10,739$. Hal ini menunjukan Terdapat pengaruh signifikan dari model pembelajaran terhadap kemampuan komunikasi matematika pada pembejaran Matematika. Pada pembelaran cooperative learning type STAD, peserta didik terlibat langsung dalam pembelajaran, mulai dari siswa memahami masalah, sampai dengan siswa menemukan konsep yang terkandung dalam masalah tersebut. Keterlibatan tersebut, bukan hanya sampai pada menemukan konsep, melainkan juga berlanjut pada kegiatan diskusi kelas, baik diskusi tentang penemuan konsep, maupun diskusi tentang hasil pengerjaan contoh dan latihan soal di depan kelas. Siswa pada kegiatan diskusi boleh memberikan tanggapan, pertanyaan, dan bahkan jawaban terkait depan kelas. Hal ini kemudian membuat siswa, bukan hanya terampil dalam menjawab soal, melainkan juga terampil dalam memberikan alasan terkait dengan jawaban yang mereka miliki. Penelitian ini sejalan dengan penelitian (Wahyuni \& Abadi, 2014) Hasil penelitian menunjukkan bahwa metode pembelajaran (type student team achiement division dan type think-pair-share) efektif dan metode tipe STAD lebih efektif daripada metode tipe TPS ditinjau dari aspek ketercapaian standar kompetensi, kemampuan komunikasi matematika, dan berpikir matematis siswa SMP.

Saat proses pembelajaran dengan metode Number Head Together (NHT) dibagi 5 tahap, yaitu: persiapan, pembentukan kelompok dan penomoran, diskusi masalah, 
pemanggilan nomor atau pemberian jawaban, dan memberikan kesimpulan. Guru melakukan persiapan (menyiapkan media pembelajaran, guru menyampaikan materi awal), kemudian membentuk kelompok (4-5 orang) (setiap kelompok mempunyai tugas masing-masing dan setiap kelompok diberi nomor), setiap kelompok melakukan diskusi sesuai dengan tugas yang diberikan, kemudian pendidik memanggil siswa sesuai dengan nomor yang diundi, siswa yang dipanggil nomornya harus menjelaskan tugas yang diberikan guru, disini siswa menggunakan kemampuan komunikasi untuk menyampaikan tugas tersebut dan siswa harus bisa memecahkan permasalahan dari setiap tugas maupun pertanyaan yang diberikan. Sehingga metode NHT dikatakan efektif dalam meningkatkan kemampuan komunikasi. Sejalan dengan (Sutisna \& Nanang, 2013) kesimpulan bahwa Kemampuan Komunikasi Matematika siswa yang menggunakan pendekatan model pembelajaran Kooperatif Number Head Together (NHT) lebih baik dibandingkan pembelajaran Konvensional.

Hipotesis ketiga menyatakan "terdapat pengaruh yang signifikan dari model pembelajaran terhadap pemecahan masalah matematika" : dari hasil pengujian yang terdapat pada tabel 6 Tests of Between-Subjects Effects di atas yang merupakan tabel utama yang mempresentasikan hasil hipotesis yang diajukan penelitidiperoleh nilai sig sebesar $0,00<0,05$ dan $\mathrm{F}$ hitung $=18,688$. Hal ini menunjukan terdapat pengaruh yang signifikan dari model pembelajaran terhadap pemecahan masalah matematika. Hal ini senada yang dilakukan oleh (Noor \& Husna, 2017) Hasil penelitian menunjukkan bahwa kemampuan pemecahan masalah matematika siswa dengan menggunakan model pembelajaran kooperatif tipe NHT berada pada kualifikasi baik dan kemampuan pemecahan masalah matematika siswa yang menggunakan model pembelajaran konvensional berada pada kualifikasi cukup.

\section{CONCLUSION}

Terdapat pengaruh yang signifikan dari model pembelajaran terhadap kemampuan komunikasi dan pemecahan masalah matematika secara multivariat. Terdapat pengaruh signifikan dari model pembelajaran terhadap kemampuan komunikasi matematika pada pembejaran Matematika. Terdapat pengaruh signifikan dari model pembelajaran terhadap kemampuan komunikasi matematika pada pembejaran Matematika.

\section{REFERENCES}

Juliani Noor, A., \& Megawati, M. (2014). Model Pembelajaran Kooperatif Tipe Numbered Heads Together (NHT) pada Pemecahan Masalah Matematika di Kelas VIII SMP. EDU-MAT: Jurnal Pendidikan Matematika, 2(1), 45-52. https://doi.org/10.20527/edumat.v2i1.600

Lagur, D. S., Makur, A. P., \& Ramda, A. H. (2018). Pengaruh Model Pembelajaran Kooperatif Tipe Numbered Head Together (NHT) terhadap Kemampuan Komunikasi Matematis. Mosharafa: Jurnal Pendidikan Matematika, 7(3), 357368. https://doi.org/10.31980/mosharafa.v7i3.160

Menanti, H., \& Rahman, A. A. \& H. M. (2015). PERBANDINGAN KEMAMPUAN PEMAHAMAN KONSEP MATEMATIKA SISWA MENGGUNAKAN MODEL PEMBELAJARAN KOOPERATIF TIPE STUDENT TEAMS ACHIEVEMENT DIVISION (STAD) DENGAN TEAM GAME TOURNAMENT (TGT) DI SD ISLAM KHALIFAH ANNIZAM. Jurnal Bina Gogik, Volume $2 \mathrm{~N}, 45$.

Muhammad, I., Nufus, H., \& Mursalin. (2017). Pembelajaran Kooperatif Tipe Stad ( 
Student Teams Chievement. Kajian Pembelajaran Matematika, 1(2), 113-118.

Noor, A. J., \& Husna, R. (2017). Meningkatkan Kemampuan Komunikasi Matematis Siswa Menggunakan Model Pembelajaran Kooperatif Tipe Student Teams Achiviement Division (STAD). EDU-MAT: Jurnal Pendidikan Matematika, 4(2). https://doi.org/10.20527/edumat.v4i2.2578

Rahman, A. A. \& H. M. (2015). Perbandingan Kemampuan Pemahaman Konsep Matematika Siswa Menggunakan Model Pembelajaran Kooperatif Tipe Student Teams Achievement Division ( Stad ) Dengan Team Game Tournament ( Tgt ) Di Sd Islam Khalifah. Jurnal Bina Gogik, 2(1), 38-48.

Rakhmawati, R. (2015). Upaya meningkatkan aktivitas dan prestasi belajar matematika siswa kelas XI IPA 1 SMAN 1 Amuntai tahun pelajaran 2013/2014 melalui pembelajaran kooperatif tipe STAD. Math Didactic: Jurnal Pendidikan Matematika, 1(2), 116-123. https://doi.org/10.33654/math.v1i2.12

Sapitri, S., \& Hartono, H. (2015). Keefektifan Cooperative Learning Stad Dan Gi Ditinjau Dari Kemampuan Berpikir Kritis Dan Komunikasi Matematis. Jurnal Riset Pendidikan Matematika, 2(2), 273. https://doi.org/10.21831/jrpm.v2i2.7346

Sutisna, E. N., \& Nanang. (2013). Pengaruh Model Pembelajaran Kooperatif Dengan Pendekatan Number Head Together ( Nht ) Terhadap Kemampuan Komunikasi Matematika Siswa. 2, 77-86.

Vhalery, R. (2019). PERBANDINGAN AKTIVITAS BELAJAR MELALUI MODEL PEMBELAJARAN KOOPERATIF TIPE GROUP INVESTIGATION DAN NUMBERED HEAD TOGETHER. Research and Development Journal of Education, 6(1), 80-93.

Wahyuni, A., \& Abadi, A. M. (2014). Perbandingan Keefektifan Pembelajaran Cooperative Learning Type Stad Dan Type Tps Pada Pembelajaran Bangun Ruang Siswa Smp. Jurnal Riset Pendidikan Matematika, l(2), 164. https://doi.org/10.21831/jrpm.v1i2.2673

Yenni, R. F. (2016). Penggunaan metode numbered head Together ( NHT ) dalam pembelajaran matematika. Jurnal Penelitian Dan Pembelajaran Matematika, 9(2), 33-42. http://jurnal.untirta.ac.id/index.php/JPPM/article/view/1006 